\title{
PERAN LPTK DALAM PEMBENTUKAN TENAGA PROFESIONAL BERBASIS SYARIAT ISLAM DI ACEH
}

\author{
Muhibbuthabry \\ Fakultas Tarbiyah IAIN Ar-Raniry \\ Jl. Darussalam, Banda Aceh, Nanggroe Aceh Darussalam, 23111 \\ e-mail: muhib_nett@yahoo.com
}

\begin{abstract}
The Role of LPTK in Creating Syari'ah Based Professional Workforce in Aceh. The Institution of Learning for Educational workforce (LPTKs) plays an important role in the process of producing professionals in their fields. This article studies the extent to which such institutional programs play, especially those mainly associated with the Islamic sya'riah implemented in Aceh region. The writer of this article argues that, in terms of quality, it can be revealed from how far the lecturers are capable of facilitating the students' learning process and its relevance to teaching materials. Therefore, the author concludes that the quality of learning can be conducted with the intensity of the systemic and synergistic lecturers, students, curriculum and learning materials, media, facilities, and learning systems in producing process and the optimal learning outcomes in accordance with the demands of curriculum.
\end{abstract}

Kata Kunci: workforce, professional, LPTK, Aceh

\section{Pendahuluan}

Ada kecenderungan keinginan melihat Lembaga Pendidikan Tenaga Keguruan (LPTK) Fakultas Tarbiyah secara kelembagaan untuk tidak terjebak tampil reaksioner dengan mencoba "mengislamkan" ilmu pengetahuan, tetapi hendaknya tampil lebih progresif mengkaji dan menelaah ajaran Islam agar bisa dijadikan sebagai teori-teori ilmu pengetahuan. ${ }^{1}$ Atau dengan istilah lainnya, Fakultas Tarbiyah hendaknya dapat berperan dalam "mengilmu pengetahuankan" ajaran-ajaran Islam dalam dunia pendidikan.

Dalam konteks Indonesia, dunia pendidikan Islam tampaknya masih berada dalam

${ }^{1}$ Komaruddin Hidayat dan Hendro Prayitno (ed.), Problem dan Prospek IAIN: Antologi Pendidikan Tinggi Islam (Jakarta: Ditperta Departemen Agasma, 2000). 
suasana yang kelam. Hal ini banyak dikeluhkan para ahli dan pemerhati pendidikan. Pendidikan dipandang masih dominan dalam fungsi pelestarian kejumudan. Seperti disinyalir Winarno Surakhmad bahwa peran pendidikan selama ini tidak lebih tidak kurang mengawetkan kepentingan kekuasaan dari monoloyalitas hingga kehidupan yang seragam. Masih adakah sedikit ruang tersisa untuk mengakui bahwa menusia diciptakan Allah beragam, berbagai potensi dan berbagai kemungkinan?-tanyanya. Dijawabnya sendiri, "Tidak ada." 2

Boleh jadi, kondisi dan model pendidikan yang demikian itulah yang mendorong Bangsa Indonesia, dari sisi SDM berposisi pada urutan ke-109 dari 173 negara dunia, jauh di bawah negara-negara tetangga seperti Malaysia ke-61, Thailand ke-76, Filipina ke-77, Singapura ke-24. Bahkan Vietnam masih di atas, pada urutan ke-108. Sejumlah negara Afrika tampil lebih atas dari Indonesia seperti Tunisia ke-101 dan Afrika Selatan ke-103. Tentu saja jauh dibanding Hongkong ke-22, apalagi Jepang yang berada pada peringkat ke-3. ${ }^{3}$ Dari sisi kekorupsian, menurut Sheredan, Indonesia terpuruk sebagai negara yang terkorup di dunia. Pertanyaannya, mengapa sampai demikian? Ya itu tadi, karena pendidikan tidak mendapat porsi perhatian yang memadai dalam berbagai upaya pembangunan bangsa ini. Akibat perlakuan yang tidak semestinya dalam menyikapi dunia pendidikan itu, kalangan pemerhati sampai memandang bahwa Indonesia telah mengalami the lost generation dalam bidang pendidikan.

Jika menoleh ke dunia pendidikan agama dalam hal ini pendidikan Islam, kondisinya lebih menyedihkan lagi, dalam keseluruhan bidangnya. Padahal ke depan, dan bahkan sejak hari-hari ini di mana Indonesia masih terus dalam krisis multi dimensi yang belum kunjung ada tanda-tanda berakhirnya, pendidikan dan pendidikan agama khususnya berposisi sangat strategis dalam membangun etika bangsa untuk mendukung etos dalam segala bidang kehidupannya. Tanpa etika, bidang apapun akan menjadi tidak karuan. Di sinilah terlihat perlunya dilihat kemungkinan-kemungkinan yang dapat mendorong daya gerak pendidikan itu, khususnya pendidikan Islam, ke arah yang lebih dinamis dan kreatif dalam kerangka membangun karakter guru yang berbasis syariat Islam.

Untuk membangun karakter tersebut, perlu adanya terobosan baru, untuk melahirkan tenaga pendidik yang profesional juga memiliki kompetensi relegius. Permasalahannya adalah bagaimana kreativitas LPTK dalam menciptakan tenaga pendidik yang berkualitas? Inilah persoalan sentral yang akan coba dicari jawabannya dalam tulisan ini.

${ }^{2}$ Disarikan dari Ahmad Gaus, "Tantangan Serius Pendidikan Agama," dalam PERTA: Jurnal Komunikasi Perguruan Tinggi Islam, No. II Vol. III (Jakarta: Ditperta dan LP2AF, 2000), h. 16.

${ }^{3}$ Dari UNDP Report 2000 dikutip Hafiz Abbas "Mengakhiri sebuah Diskriminasi," dalam PERTA: Jurnal Komunikasi Perguruan Tinggi Islam, No. II Vol. III (Jakarta: Ditperta dan LP2AF, 2000), h. 46. 


\section{Tuntutan Belajar Kreatif}

Pada prinsipnya, rangkaian wahyu yang pertama sekali diterima Nabi Muhammad SAW. ${ }^{4}$ penuh dan sarat dengan konsep yang bernuansa edukatif khususnya tentang belajar. Diantaranya iqra' pada ayat pertama dan ketiga, 'allama pada ayat keempat dan kelima, serta qalam pada ayat keempat dari surah al-'Alaq.

Dalam mengomentari konsep iqra', para mufasir umumnya menceritakan dialog yang terjadi antara malaikat Jibril sebagai pembawa dengan Nabi SAW. sebagai penerima wahyu. Hampir secara keseluruhan-untuk tidak mengatakan seluruhnya-mufasir memandang Nabi Muhammad SAW. sebagai tidak pandai membaca, sehingga ketika disuruh "membaca" selalu menjawab dengan mâ ana biqâri’5 atau mâ aqra' sampai berulang tiga kali. Nabi SAW. dipandang tidak bisa membaca memang bukannya tanpa alasan, di samping penjelasan dari Allah sendiri, ${ }^{6}$ tetapi juga akan menjadi lebih jelas setelah konsep iqra' itu sendiri dipahami serta bahwa perintah membaca itu sendiri pada dasarnya tidak hanya ditujukan kepada Nabi SAW. secara pribadi saja, tetapi juga kepada manusia umumnya untuk kepentingan kemanusiaannya. Hal lain yang dapat membantu menjelaskan permasalahan tersebut adalah bahwa obyek bacaan itu sendiri tidak dijelaskan, di mana Jibril tidak membawa tulisan, jadi obyeknya dapat dipandang umum mencakup apa saja yang dapat dijangkau oleh kata tersebut. Dalam hal ini para mufasir cukup beragam.

Di antaranya yang dapat dipandang kuat adalah pandangan Muhammad Abduh, bahwa perintah membaca iqra' pada ayat pertama dari wahyu pertama itu termasuk dalam kategori al-amr al-takwini yakni perintah Allah untuk menjadikan sesuatu. Nabi SAW. ketika itu memang tidak pandai membaca maupun menulis. Karena itu, beliau mengulang-ulang ucapannya mâ ana biqari'. Kemudian datanglah perintah Ilahi agar ia menjadi pandai membaca walaupun tetap tidak pandai menulis. Sebab akan diturunkan kepadanya kitab yang akan dibacanya, meski ia tidak dapat menuliskannya. Itulah sebabnya ayat tersebut melukiskan Tuhan sebagai 'Yang menciptakan.' Dzat yang meyandang sifat-sifat yang dengannya Ia mampu menanamkan pengaruh-Nya pada segala macam ciptaan-Nya yang tidak terhingga, pastilah ia mampu juga menciptakan kepandaian membaca. Maka seolah-olah Allah SWT. berfirman kepada Nabi SAW. "Jadilah engkau pandai membaca dengan qudrat dan iradah-Ku."

Adapun yang menjadi obyek bacaan itu adalah 'nama' (nama Tuhan-mu), sebab 'nama' mengantarkan kepada pengetahuan tentang dzat yang punya nama. Akan tetapi-

${ }^{4}$ Secara kronologis disepakati oleh para mufasir bahwa Q.S. al-Alaq/96: 1-5 merupakan wahyu pertama yang diturunkan dan diterima Nabi Muhammad SAW. Hal ini disebutkan di hampir keseluruhan kitab tafsir yang menafsirkan surah yang bersangkutan.

${ }^{5}$ Sayyid Qutb, Fî Zhilâl al-Qur'ân, Jilid VIII (Kairo: Dâr al-Syurûq, t.t.), h. 197.

${ }^{6}$ Q.S. al-Ankabût/39: 48. Ayat tersebut menjelaskan ketidakbisaan Nabi Muhammad SAW. dalam membaca maupun menulis, sebab bila Nabi bisa membaca dan menulis akan menambah keraguan orang-orang yang tidak beriman. 
komentar 'Abduh lebih lanjut-apabila diartikan perintah ini sebagai suatu kewajiban yang dibebankan al-amr al-taklifi dengan menyatakan bahwa maknanya adalah bahwa kamu diperintah-ketika membaca sesuatu-agar membacanya dengan nama Allah, maka arti ayat itu adalah 'apabila kamu membaca, hendaknya kamu selalu membaca dengan pengertian bahwa bacaanmu itu merupakan perbuatan yang kamu laksanakan demi Allah saja, bukan demi sesuatu yang lain'. ${ }^{7}$ Kalaupun diperkirakan bahwa seseorang membaca, dengan menjadikan bacaannya itu demi Allah sendiri, bukan demi yang selainNya, tetapi ia tidak menyebut nama-Nya, maka ia tetap dianggap membaca demi Allah. Anjuran untuk mengucapkan basmallah dengan lisan, adalah semata-mata untuk mengingatkan hati-pada permulaan setiap pekerjaan—agar senantiasa kembali kepada Alah SWT. dalam perbuatan tersebut.

Pengulangan kata iqra' pada ayat ketiga, banyak dipandang sebagai taukid dan penyempurnaan kalam yang kemudian diiringi dengan penyebutan identitas sang Pencipta sebagai Yang Maha Mulia. Bagi 'Abduh, pengulangan itu merupakan peyakinan kepada diri Nabi SAW. yang tadinya tidak bisa membaca, bahwa kini setelah datang perintah yang berulang itu, sungguh-sungguh Nabi SAW. menjadi dapat membaca. ${ }^{8}$ Membaca untuk dapat menguasai pembacaan itu dalam dunia realitas-historis juga memerlukan pengulangan-pengulangan, sehingga adalah sangat dapat dipahami bila pengulangan dalam al-Qur'an dipahami ke arah itu, untuk lebih menguasai dan meyakini kepenguasaan atas suatu kemampuan yang baru diperoleh.

Lalu bagaimana dengan pengertian iqra' itu sendiri? Dalam hal ini para mufasir banyak menyinggung posisi dan fungsi dari iqra' itu dalam konteks kalimat-kalimat ayat al-Qur'an. Kata iqra' muncul dalam al-Qur'an sebanyak tiga kali, masing-masing pada Q.S. al-Isrâ'/17: 14 dan Q.S. al-'Alaq/96: 1 dan 3. Sedangkan akar kata tersebut dalam berbagai bentuknya terulang sebanyak 17 kali, selain kata al-Qur'an sebanyak 70 kali. Obyek dari kata-kata "membaca" dalam al-Qur'an khususnya yang berakar pada qara'a terkadang menyangkut suatu bacaan yang bersumber dari Tuhan (al-Qur'an atau kitab suci sebelumnya), dan terkadang juga obyeknya suatu kitab yang merupakan himpunan karya manusia. ${ }^{9}$ Di sisi lain dapat dipahami bahwa jika memang sesuatu kata dalam suatu redaksi tidak disebutkan obyeknya, maka obyek yang dimaksud itu bersifat umum, mencakup segala sesuatu yang dapat dijangkau oleh kata tersebut.

Dari analisis tersebut bisa dimengerti bahwasanya kata iqra' dapat dipandang sebagai mengandung makna yang luas dan beragam, antara lain "menyampaikan, menelaah, membaca, mendalami, meneliti, mengetahui ciri-cirinya, dan sebagainya." ${ }^{10}$

${ }^{7}$ Muhammad Rasyid Ridho, Tafsîr al-Qur'ân al-Karîm: Juz 'Ammâ (Kairo: Dâr al-Masyriq, t.t.), h. $248-249$.

8Ibid., h. 250.

${ }^{9}$ Untuk yang pertama contohnya Q.S. Yûnus/10: 94; dan untuk yang kedua Q.S. alIsrâ'/17: 14.

${ }^{10}$ M. Quraish Shihab, Membumikan al-Qur'an (Bandung: Mizan, 1992), h. 167-171. 
Jadi, iqra' adalah memang sangat kental dan sarat dengan muatan konsep belajar dalam arti yang seluas-luasnya dan sepenuh-penuhnya. Sudah tentu juga sangat erat berkaitan dengan konsep 'allama dan qalam yang akan dianalisis berikut ini.

Term 'allama muncul dua kali dalam Q.S. al-Alaq/96: 4-5. Pertama dalam arti pengajaran manusia dengan pena. Kedua dalam arti pengajaran manusia hal-hal yang belum diketahuinya, sedangkan qalam muncul hanya sekali pada ayat keempat dalam redaksi 'allama bi al-qalam alama al-insâna mâ lam ya'lam. Pentingnya penggunaan qalam dalam pengajaran Tuhan terhadap manusia digambarkan Quthb bahwa karena qalam masih dan senantiasa berpengaruh luas dan mendalam pada kehidupan manusia, sebagai alat pengajaran, yang pada waktu itu kenyataan ini belum nampak dalam kehidupan manusia, tetapi Allah mengetahui arti dan nilai qalam bagi manusia, hingga Dia mengisyaratkan alat ini pada awal langkah dari langkah-langkah risalah terakhir ini. ${ }^{11}$

Dalam ayat yang sedang dibicarakan ini, kata qalam yang digunakan berarti "alat" tetapi yang dimaksudkan adalah hasil dari kegunaannya yaitu "tulisan." Sebab sulit dibayangkan dan sulit menggambarkan bagaimana terjadinya pengajaran dengan qalam. Untuk dapat lebih memahami hal ini kiranya adalah perlu mencari hubungannya dengan ayat/surah lain, dalam hal ini adalah ayat pertama dari Q.S. al-Qalam/64, yakni nun wa al-qalami wa mâ yasthurûn. Ayat ini turun adalah kedua setelah wahyu pertama, berarti persis setelah ayat kelima dari Q.S. al-Alaq/96. Karena itu dapat dipahami bahwa yang dimaksud dengan qalam di sini adalah hasil penggunaan qalam itu sendiri, tulisan. ${ }^{12}$

Sedangkan menyangkut bahan ajar, yang diajarkan dengan atau dalam proses pembelajaran dengan qalam itu, para mufasir juga berbeda pendapat. Ada yang berpandangan seperti yang telah disinggung di atas, karena obyeknya tidak dijelaskan maka itu berarti umum, apa saja yang dapat dijangkau. Namun demikian, ada pula yang mengkaitkan proses pembelajaran itu dengan pembelajaran Adam oleh Allah ketika hendak dijadikan sebagai khalifah dan digugat oleh malaikat, yang diceritakan dalam Q.S. al-Baqarah/2: 30-34.

Mengenai apa yang diajarkan Allah kepada Adam, yang terkandung dalam penggalan redaksi ayat wa 'allama âdama al-asmâ' kullaha para mufasir berbeda pendapat. Bintusy Syathi' merangkum perbedaan pandangan mufasir tersebut khususnya tentang al-asmấ kullaha dengan menyatakan bahwa ada yang memandang yang dimaksudkan adalah bahasa berupa hurf, fiil dan isim. Ini senada dengan pihak yang berpendapat bahwa namanama itu adalah bahasa-bahasa, sehingga termasuk semua bahasa yang digunakan Adam dan anak cucunya. Ada pula yang menyatakan bahwa yang diajarkan itu adalah namanama malaikat. Mufasir lain menggeneralisir ke dalam nama semua benda, seperti unta, kambing, tikus dan lainnya. Ada yang menambahkan dengan nama jin dan binatang

${ }^{11}$ Quthb, Fî Zhilâl al-Qur'ân, h. 202.

${ }^{12}$ Ibid., h. 28. 
liar, serta nama anak cucu Adam. Ada pula yang menyatakan bahwa Allah mengajarkan nama-nama benda dengan segala sifat, manfaat atau kegunaan benda-benda tersebut baik manfaat keagamaan maupun keduniaan. ${ }^{13}$

Merujuk kepada al-Zamakhsyarî, Bintusy Syathi' menyatakan bahwa kekhalifahan dan potensi ilmiah yang dimiliki Adam itu juga berlaku untuk semua manusia, karena ungkapan-ungkapan malaikat dalam ayat bersangkutan adalah tentang sifat manusia dalam bentuk jama'. Juga karena yang diserahi kekhalifahan itu semua manusia, maka semua manusia juga dibekali dengan kekuatan ilmiah. Dari sekian pandangan para mufasir yang dicermatinya, Bintusy Syathi' kemudian menyimpulkan bahwa penghormatan kepada manusia pertama, seperti terungkap dalam perintah Allah kepada malaikat untuk bersujud kepadanya, jelas merupakan kelebihan Adam karena hanya dia yang mampu menggali pengetahuan yang malaikat tidak mampu mengetahuinya. Keberpengetahuan inilah ternyata yang merupakan argumen utama dari penunjukan Adam sebagai khalifahNya. ${ }^{14}$

Dari analisis tentang proses penciptaan manusia diketahui bahwa sesungguhnya dalam diri manusia telah tersedia potensi jasadiah dan rohaniah, potensi mental-spiritual serta rasional-intelektual yang dapat menjadi fasilitas-fasilitas utamanya dalam proses menjadi berpengetahuan, dalam proses belajar. Kemudian dari analisis tentang karakteristik manusia juga diketahui bahwa dalam dirinya terdapat potensi positif disamping potensi negatif yang akan saling bersaing dalam merebut pengaruh terhadap diri manusia. Perebutan pengaruh ini (positif-negatif) ini akan terus berlangsung tanpa henti sepanjang karier kehidupannya, dan itulah ujian yang harus selalu ditempuh manusia, bahkan hingga kematiannya, untuk mencapai predikat siapa yang paling unggul. ${ }^{15}$ Untuk kepentingan yang disebut terakhirpun sangat memerlukan belajar dan belajar.

\section{Konsep Syariat Islam}

Syariat menurut istilah merupakan suatu ketetapan (hukum-hukum) Allah untuk hamba-Nya dalam bentuk agama. Allah telah menetapkan suatu syariat bagi manusia sebagai suatu jalan yang telah ditetapkan. ${ }^{16}$ Syariat juga diartikan sebagai sesuatu yang telah ditetapkan Allah terhadap para hamba-Nya dalam bentuk hukum yang telah dibawa oleh salah seorang nabi di antara nabi-nabi lainnya, yaitu Nabi Muhammad SAW, baik yang menyangkut dengan tatacara beramal yang disebut juga far'iyyah dan 'amaliyyah yang dikodifikasikan dalam ilmu fiqih, maupun yang menyangkut dengan persoalan

\footnotetext{
${ }^{13}$ Aisyah Abdurrahman (Bintusy-Syathi'), Maqal fì al-Insân: Dirâsah Qur'aniyah, terj. M. Adib al-Arief (Yogyakarta: LKPSM, 1997), h. 42-43.

${ }^{14} I b i d .$, h. 46, 49.

${ }^{15}$ Q.S. al-Mulk/67: 2.

${ }^{16}$ Al-Qurthûbî, al-J âmi' li Ahkâm al-Qur'ân, jilid IV (Beirut: Dâr al-Kutûb al-'Ilmiyyah, t.t.), h. 211.
} 
kepercayaan (ittiqâd) yang disebut juga ashliyyah dan ittiqâdiyyah yang dikodifikasikan dalam ilmu Kalam. ${ }^{17}$

Al-Asyqar ${ }^{18}$ menyebutkan bahwa ulama abad pertama Islam mendefinisikan syariat secara terminologi sama dengan definsi fiqih, karena keduanya mencakup agama secara keseluruhan, baik akidah, hukum, dan adab sopan santun. Demikian pula menurut ulama mutaakhkhirîn karena keduanya membahas persoalan hukum amaliah. Perbedaan antara keduanya sangat kecil, karena syariat merupakan agama yang diturunkan dari sisi Allah, sedangkan fiqih ialah pemahaman terhadap syariat tersebut.

Dalam bahasa Arab, kata syariat dipergunakan dalam arti jalan yang lurus. Pada bentuk ini kata syariat sesuai dengan apa yang termaktub dalam Q.S. al-Jatsiyat/45: 18:

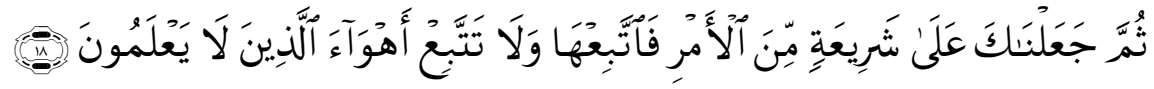

Kemudian Kami jadikan kamu berada di atas suatu syariat (peraturan) dan urusan agama itu, maka ikutilah syariat itu dan janganlah kamu ikuti hawa nafsu orang-orang yang tidak mengetahui.

Kata "syariat" juga dipandang sama dengan al-syir'ah, seperti disebutkan dalam Q.S. al-Maidah/5: 48. Dengan penjelasan ayat tersebut, maka syariat dipandang sebagai jalan yang lurus yang tidak berliku-liku dan tikungan padanya, sebagaimana juga pemakaian istilah sumber air dalam sumber untuk minum ${ }^{19}$. Lebih jauh para fuqaha Muslim memahami pengertian syariat sebagai hukum-hukum yang telah ditetapkan Allah terhadap hambahamba-Nya melalui perantaraan seorang rasul di antara rasul-rasul lainnya. ${ }^{20}$

${ }^{17} \mathrm{Jad}$ al-Haq 'Alî Jad al-Haq, Al-Fiqih al-Islâm: Nasy'atuhu wa Tathawwuruh (Kairo: Ma'had al-Dirâsah al-Islâmiyyah, 1986), h. 5.

${ }^{18}$ Terdapat beberapa perbedaan antara terminologi fiqih dengan syariah menurut ulama mutaakhirîn; (1). Hubungan antara fiqih dan syariah, secara umum dan khusus dari satu segi. Keduanya bertemu pada hukum yang sesuai dengan Hukum Allah (syariah). Fiqih berbeda dengan syariah pada hukum hasil istinbath para mujtahid yang salah dan syariah itu terpisah dari fiqih pada hukum-hukum yang berkenaan dengan akidah, akhlak dan kisah-kisah orang dahulu. (2). Syariah itu sempurna, berbeda dengan fiqih. Syariah mencakup kaedah dan dasardasar umum yang dari dasar-dasar dan kaedah tersebut disandarkan hukum-hukum yang tidak dinashkan dalam seluruh persoalan hidup, sedangkan fiqih itu adalah pendapat para mujtahid dari kalangan para ulama. (3). Syariah berlaku untuk umum, tidak seperti fiqih. Keumuman tersebut dapat dilihat dari fakta syariah, sasaran dan nash-nashnya yang ditujukan kepada seluruh manusia. (4). Syariah diwajibkan kepada semua manusia. Maka setiap orang yang telah memenuhi syarat taklif, wajib melaksanakannya. Sementara fiqih merupakan hasil ijtihad para ulama yang tidak wajib diikuti oleh mujtahid lain, bahkan oleh para muqallid-nya, jika ia mendapatkan pendapat mujtahid lain yang lebih baik. (5). Syariah itu berisi kebenaran semata, sementara fiqih sebagai pemahaman fuqaha terhadap Syariah, terkadang salah dan terkadang benar. 6. Syariah itu tetap dan kekal. Uraian Umar Sulaiman al-Asyqar, Fiqih Islam Sejarah Pembentukan dan Perkembangannya, terj. Dedi Djunaidi dan Ahmad Nurahman (Jakarta: Akademika Pressindo, 2001), h. 15-17.

${ }^{19}$ Juhaya S. Praja, Filsafat Hukum Islam (Bandung: LPPM, 2002), h. 10.

${ }^{20}$ Muhammad Musthafa Syalabi, Al-Madkhal fĩ al-Ta'ârif bi al-Fiqh al-Islâmi (Beirut: Dâr al-Nahdah al-'Arabiyah, 1968), h. 27. 
Penyebutan hukum-hukum atau ketentuan-ketentuan dimaksud sebagai syariat, karena memiliki konsistensi dan tidak menyimpang dari jalan yang lurus, sebagaimana ia mempunyai kesamaan dengan jalan ke sumber air minum yang menjadi sumber kehidupan bagi makhluk hidup. Untuk itu, syariat dan agama mempunyai konotasi yang sama. ${ }^{21}$ Mahmud Syaltut menyebutkan bahwa syariat adalah sebuah nama bagi suatu sistem dan hukum-hukum yang telah ditetapkan Allah atau ketetapan dasarnya yang bersifat taklifi bagi umat Islam sebagai pegangan bagi diri mereka dalam hubungannya dengan Allah dan hubungan sesama manusia. Secara garis besarnya syariat itu mencakup dua hal, yaitu ibadah dan muamalah. ${ }^{22}$

Dengan demikian, syariat dalam disertasi ini adalah suatu sistem yang mengatur kehidupan manusia khususnya tindakan mukallaf dalam tata hubungan dan tindakan yang bersifat vertikal kepada Allah dalam bentuk ibadah dan mengatur hubungan dan tindakan manusia secara horizontal dalam bentuk muamalah. Untuk itu pemakaian istilah syariat bersifat temporal dan spiritual, karena kata ini mengandung pengertian sebagai jalan kehidupan yang baik berupa nilai-nilai agama yang diungkapkan secara fungsional dan dalam makna yang lebih kongkrit sebagai jalan untuk mengarahkan kehidupan manusia yang baik dan benar serta sah secara hukum.

Sementara itu, kata "Islam", dari aspek kebahasaan menunjuk kepada pengertian tunduk (al-inqiyâd) dan dalam pengertian berserah diri kepada Allah (istisl âm li Allâh). Bahkan kata "Islam" merupakan kata jadian (mashdar) dari "aslama" sebagaimana disebutkan dalam Q.S. al-Baqarah/2: 131, Q.S. al-Mâidah/5: 44 dan Q.S. al-Zumâr/54. Secara istilah, kata "Islam" menunjuk pada agama yang diturunkan Allah kepada Rasul-Nya untuk mengatur hubungan manusia dengan Tuhan-Nya, mengatur dirinya sendiri dan mengatur hubungan sesama manusia. $^{23}$

Karena itu, maka istilah "Islam" dikhususkan kepada agama yang telah disyariatkan Allah kepada Nabi Muhammad SAW. Pemakaian kata Islam sebagai agama, sebagaimana termaktub dalam Firman Allah Q.S. al-Mâidah/5: 3:

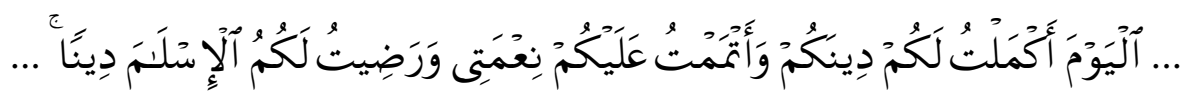

Hari ini Aku telah menyempurnakan untuk kamu agamamu dan Aku cukupkan nikmat untukmu dan meridhai Islam sebagai agama kamu.

Berdasarkan ungkapan-ungkapan di atas dapat disimpulkan bahwa secara substantif syariat Islam lebih luas dan lengkap dari undang-undang yang dikenal dalam perundangperundangan konvensional Barat (Eropa) seperti Anglo-Saxon dan Kontinental. Karena

\footnotetext{
${ }^{21}$ Ibn Al-Manzur, Lisan al-Arâb, juz XI (Beirut: Dâr al-Ilmiyah, t.t.), h. 631.

${ }^{22}$ Syaltut, Islâm, h. 73.

${ }^{23}$ Al-Nabhani, Nizâm al-Islâm, cet. 6 (Beirut: Mansyûrat Hizb al-Tahrir, 2001), h. 69.
} 
itu, al-Asyqar ${ }^{24}$ mengutip pendapat Nalino seorang orientalis mengatakan bahwa tidak mungkin ditemukan dalam bahasa Barat istilah dapat menyamai arti kata syariat. Karena syariat membahas berbagai persoalan yang menyangkut hubungan antara seorang Muslim dengan Allah, dengan dirinya dan dengan sesamanya. Nalino berkesimpulan bahwa syariat memuat lebih banyak tentang berbagai aspek hukum dari pada undang-undang yang dimaksud oleh orang-orang Barat.

\section{Telaah tentang Implikasi Pendidikan dan Kreativitas}

Dunia belajar mengajar dewasa ini seiring dengan perkembangan ilmu pengetahuan yang mampu dicapai manusia, khususnya tentang dirinya sendiri seperti fisiologi, biologi, psikologi, psikoterapi dan lainnya telah berkembang cukup pesat. Sistem pendidikan konvensional, yang mengandaikan guru (pengajar) di satu pihak sebagai yang serba tahu dan siswa (si-belajar) di pihak lain sebagai serba tidak tahu, guru di satu pihak sebagai yang berkuasa (pemegang otoritas) sementara siswa di pihak lain sebagai yang dikuasai (tidak berdaya), sudah tidak lagi mampu memberi kontribusi bagi kemajuan kemanusiaan dan karenanya secara bertahap sudah mulai ditinggalkan. Dalam dunia pendidikan dan dunia belajar mengajar gaya lama, siswa atau si belajar cenderung dipandang sebagai "bejana" yang kosong dan siap diisi, sehingga mengajar dipahami sebagai "proses menanamkan pengetahuan kepada anak atau proses penyampaian kebudayaan kepada anak." Padahal siswa adalah manusia yang "utuh" yang punya perasaan dan punya "aku" dan karenanya punya "harga diri" seperti halnya guru. Jadi seyogyanya siswa tidak diperlakukan sebagai "pesakitan" yang selalu menjadi ajang untuk melampiaskan tempat salah dan kemudian memberinya yang "benar dan baik." Atau siswa seyogianya tidak lagi di perlakukan sebagai "bawahan" yang siap diperintah dan bahkan dikuasai oleh sang guru. Dalam konteks ini kiranya adalah tepat ungkapan pengumpamaan seorang pendidik Rusia yang menyatakan "mahasiswa ataupun siswa (si-belajar) bukanlah kendaraan yang akan dan harus diisi, melainkan suatu lampu yang harus dinyalakan." ${ }^{25}$

Hasil-hasil penelitian mutahir di bidang sains humanistik menunjukkan bahwa dalam diri manusia tersimpan potensi dan kekuatan yang luar biasa besarnya, batas akhir dari besaran potensi dan kekuatan itu hingga kini belum ada bukti yang jelas yang menunjukkannya. Dalam hal ini, melalui rangkaian penelitian dan pengalaman empiriknya, Anthony Robbins kemudian melaporkan banyak hal tentang kekuatan manusia, yang melampaui batas-batas yang terlihat secara empiris. Di antara sekian banyak temuannya itu tercemin dalam ungkapan bahwa "Kalau anda hanya dapat mencintai, anda dapat

\footnotetext{
${ }^{24}$ Al-Asyqar, Fiqih Islam: Sejarah Pembentukan dan Perkembangannya (Jakarta: Akademika Pressindo, 2001), h. 37.

${ }^{25}$ J.A.Battle dan R.L.Shannon, Gagasan Baru dalam Pendidikan, terj. Sans S.Hutabarat (Jakarta: Mutiara, 1982), h. 16.
} 
menjadi orang yang paling kuat di dunia." ${ }^{26}$ Sehubungan dengan itu, penelitian di bidang psikologi keberhasilan, menunjukkan bahwa keberhasilan seseorang yang berhasil, ditentukan IQ tidak lebih dari 25\% dan lainnya adalah emosi menjadi sangat determinan.

Merespons semuanya itu, kini telah bermunculan gagasan-gagasan baru dalam pendidikan khususnya dalam interaksi edukatif, dalam proses belajar mengajar. Di antaranya yang dikenal dengan Studen Active Learning (SAL) atau di Indonesia yang dikenal dengan "Cara belajar Siswa Aktif (CBSA)" di mana guru dan siswanya sekaligus sama-sama aktif. Sebab yang belajar adalah siswa, jadi dia harus aktif. Penghargaan atas "keberadaan" si belajar dalam proses belajar adalah merupakan sesuatu yang "niscaya" dalam pendidikan yang diharapkan dapat berhasil secara efetif.

Pada suatu konferensi pendidikan internasional yang diselenggarakan UNESCO dikeluarkan sebuah rekomendasi, yang di antaranya menyangkut hubungan guru-siswa, di situ dinyatakan bahwa efektivitas pendidikan sekolah sebagian besar tergantung dari perkembangan hubungan baru antara guru dan siswanya, yang menjadi partner yang semakin aktif di dalam proses pendidikan. ${ }^{27}$

Dalam merespons perkembangan-perkembangan yang terjadi secara tanpa henti itu, memang banyak model pendidikan dan khususnya proses belajar yang ditawarkan yang didasarkan penelitian-penelitian yang dilakukan secara terus menerus. Di antaranya adalah konsep yang ditawarkan Paulo Freire dalam bentuk umumnya "Pendidikan Pembebasan". Ia menghadapkan konsep tersebut dengan konsep pendidikan konvensional yang disebutnya dengan pendidikan "gaya bank" (banking system) yang mengandaikan siswa sebagai "bejana yang nrimo", yang siap diisi seperti halnya mengisi "celengan" atau tabungan. Menurutnya, pendidikan model begini ini hanya akan menghasilkan manusia-manusia yang "terpola", manusia-manusia yang "jinak", manusia-manusia yang "penurut" dan sangat cocok untuk kepentingan-kepentingan tertentu, yang memang memiliki kepentingan untuk dipertahankan. Salah satu bentuk yang dipandangnya kongkrit dari model "pendidikan pembebasan" itu adalah pendidikan hadap-masalah (problem-possing). ${ }^{28}$

Bagi Freire pendidikan yang membebaskan, serta pendidikan yang efektif adalah berisi laku-laku pemahaman (acts of cognition) bukannya pengalihan informasi. Dalam pendidikan hadap-masalah, dialog antara guru-nya siswa dengan siswanya guru tidak ada lagi, dan segera muncul suasana baru: guru yang siswa dan siswa yang guru. Guru tidak lagi menjadi orang yang mengajar dan siswa diajar. Tetapi guru mengajar dirinya sendiri melalui dialog dengan siswa yang pada gilirannya juga mengajar. Mereka semua

${ }^{26}$ Anthony Robbins, Unpower Limit: Kekuatan Tanpa Batas, terj. T. Zaini Dahlan (Jakarta: Pustaka Delapratasa, 2000), h. 367.

${ }^{27}$ Norman M. Goble, Perubahan Peranan Guru, terj. Suryatin (Jakarta: Gunung Agung, 1983), h. 201.

${ }^{28}$ Paulo Freire, Pendidikan Kaum Tertindas, terj. Utomo Dananjaya et al. (Jakarta: LP3ES, 1972), h. 61. 
bertanggung jawab secara bersama terhadap suatu proses di mana mereka tumbuhberkembang untuk kepentingan kemanusiaan secara lebih luas. ${ }^{29}$

Dalam konteks pendidikan dan khususnya belajar dalam al-Qur'an, nampaknya secara umum dan mendasar terdapat kesearahan penemuan-penemuan mutaakhir di bidang pendidikan atau pembelajaran dengan apa yang telah diintrodusir jauh sebelumnya dalam al-Qur'an. Konsep belajar dalam Q.S. al-Alaq/96: 1-5, pada dasarnya dapat dipandang sebagai model belajar "hadap-masalah", di mana perintah "membaca" diiringi dengan arah atau obyek (menurut sebagian mufasir) yang harus dipahami penuh dengan konsepkonsep problematis, penuh dengan muatan-muatan permasalahan yang menuntut pemecahan kreatif. Untuk menyebut contoh lain adalah dialog antara Ibrahim dengan putranya Ismail di seputar "mimpi-benar" sang ayah. Ibrahim tidak memaksakan kehendaknya untuk melakukan "mimpi-benar" itu, tetapi menanya dan berdialog terlebih dahulu, ${ }^{30}$ secara bebas.

Kebebasan, tanpa tekanan dari pihak mana dan apapun, merupakan prasyarat bagi tumbuh-kembangnya kreativitas. Jika diingat, bahwa sejak masa Yunani Kuno dulu pun, orang belajar-menuntut ilmu adalah dalam waktu dan suasana yang bebas tanpa tekanan. Itulah sebabnya bahwa belajar dan menuntut ilmu itu dinamakan ber-sekolah (schole secara etimologis berarti zaman waktu luang). ${ }^{31}$

Dalam rangka proses belajar yang lebih efektif bagi peserta didik khususnya, Ivan Illich mengusulkan adanya upaya pembinaan dan peningkatan empat jaringan belajar. Pertama, jasa referensi pada obyek-obyek pendidikan yang memudahkan akses pada barang atau proses yang digunakan untuk kegiatan belajar yang forma. Kedua, pertukaran keterampilan, yang memungkinkan orang untuk mendaftarkan ketrampilan mereka, dalam kondisi seperti apa mereka mau menjadi model untuk orang lain yang ingin mempelajari ketrampilan ini, dan alamat di mana mereka bisa dihubungi. Ketiga, mencari teman sebaya yang cocok, suatu jaringan komunikasi yang memungkinkan orang memaparkan kegiatan belajar yang ingin mereka ikuti; keempat jasa referensi pada para pendidik pada umumnya, yang bisa didaftar dalam sebuah buku petunjuk untuk dapat menghubungi para profesional, semi profesional dan para ahli yang tidak terikat dengan lembaga tertentu. ${ }^{32}$ Dengan jasa internet dan berbagai media informasi mutaakhir dewasa ini, sebenarnya realisasi usulan Illich itu menjadi lebih mungkin.

Akhirnya, mengenai dunia pendidikan termasuk pendidikan agama Islam tentu saja, seharusnyalah dilakukan perenungan ulang secara substansial dalam berbagai aspeknya, sehingga pendidikan dapat memenuhi berbagai fungsinya yang sangat strategis dalam memfasilitasi umat manusia mencapai tujuannya untuk hidup bermartabat. Dalam kerangka

${ }^{29}$ Ibid., h. 62-70.

${ }^{30}$ Q.S. al-Shaffât/37: 102.

${ }^{31}$ Ivan Illich, Membebaskan Masyarakat dari Belenggu Sekolah, terj. Sony Keraf (Jakarta: PSH \& OBOR, 2000), h. xi.

${ }^{32}$ Ibid, h. 103-139. 
umum itulah terlihat relevansi yang kuat dari apa yang digariskan UNESCO mengenai pendidikan sepanjang hayat yang perlu dikembangkan menyongsong millenium baru ini, yaitu pendidikan yang ditopang oleh empat pilar 1) learning to know yang juga dapat berarti learning to learn, belajar untuk memperoleh pengetahuan dan untuk melakukan pembelajaran selanjutnya; 2) learning to do, belajar untuk memiliki kompetensi dasar dalam berhubungan dengan situasi dan tim kerja yang berbeda-beda; 3) learning to be, belajar untuk mengaktualisasikan diri sebagai individu dengan kepribadian yang memiliki timbangan dan tanggung jawab pribadi.; dan 4) learning to live together, belajar untuk mampu mengapresiasi dan mengamalkan kondisi saling ketergantungan, keaneka-ragaman, saling memahami dan perdamaian inter dan antar bangsa ${ }^{33}$ Jika mampu dan berhasil dalam merumuskan langkah kebijakan dunia pendidikan dengan mengikuti pola perkembangan tuntutan kebutuhan masyarakat, maka pendidikan akan menjadi berfungsi kreatif dan dinamis dalam melayani masyarakat pada setiap masanya.

\section{Penutup}

Lembaga Pendidikan Tenaga Kependidikan (LPTK) merupakan suatu lembaga yang tidak terpisahkan dalam upaya menyukseskan penerapan syariat Islam di Aceh. Penerapan syariat Islam meniscayakan adanya lembaga yang mampu mendidik tenaga guru yang dapat berkiprah di dalam masyarakat. Guru secara kebersahajaan memiliki tanggung jawab yang besar untuk menyampaikan pesan-pesan Allah yang terakumulasi dalam istilah "syariat" kepada peserta didiknya.

LPTK harus mampu berperan aktif dalam menghasilkan tenaga guru atas dasar kompetensinya sesuai dengan standar yang ingin dicapai. Dalam kaitannya dengan kiprahnya, LPTK sudah seharusnya melakukan perenungan ulang secara substansial dalam berbagai aspeknya, sehingga pendidikan dapat memenuhi berbagai fungsinya yang sangat strategis dalam memfasilitasi umat manusia mencapai tujuannya untuk hidup bermartabat.

\section{Pustaka Acuan}

Abbas, Hafiz. "Mengakhiri sebuah Diskriminasi," dalam PERTA: Jurnal Komunikasi Perguruan Tinggi Islam, No. 2 Vol. III. Jakarta: Ditperta \& LP2AF, 2000.

Abdurrahman, Aisyah. Maqal fí al-Insân: Dirâsah Qur'âniyah, terj. M. Adib al-Arief. Yogyakarta: LKPSM, 1997.

Al-Asyqar. Fiqih Islam: Sejarah Pembentukan dan Perkembangannya. Jakarta: Akademika Pressindo, 2001.

${ }^{33}$ Lihat dan bandingkan dengan http://www.unesco.org/delors/utopia.htm. 
MIQOT Vol. XXXV No. 1 Januari-Juni 2011

Al-Asyqar, Umar Sulaiman. Fiqih Islam Sejarah Pembentukan dan Perkembangannya, terj. Dedi Djunaidi dan Ahmad Nurahman. Jakarta: Akademika Pressindo, 2001

Battle, J.A. dan R.L.Shannon. Gagasan Baru dalam Pendidikan, terj. Sans S. Hutabarat. Jakarta: Mutiara, 1982.

Freire, Paulo. Pendidikan Kaum Tertindas, terj. Utomo Dananjaya, et al. Jakarta: LP3ES, 1972.

Gaus, Ahmad. "Tantangan Serius Pendidikan Agama," dalam PERTA: Jurnal Komunikasi Perguruan Tinggi Islam, No. 2 Vol. III. Jakarta: Ditperta \& LP2AF, 2000.

Goble, Norman M. Perubahan Peranan Guru, terj. Suryatin Jakarta: gunung Agung, 1983.

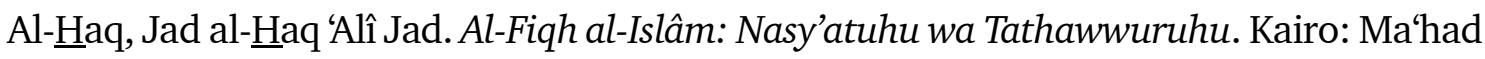
al-Dirâsah al-Islâmiyyah, 1986.

Hidayat, Komaruddin dan Hendro Prayitno (ed.). Problem dan Prospek IAIN: Antologi Pendidikan Tinggi Islam. Jakarta: Ditperta Dep. Agama, 2000.

Ibn Rusn, Abidin. Pemikiran Al-Ghazali tentang Pendidikan. Yogyakarta: Pustaka Pelajar, 1998.

Illich, Ivan. Membebaskan Masyarakat dari Belenggu Sekolah, terj. Sony Keraf. Jakarta: PSH \& OBOR, 2000.

Al-Manzur, Ibn. Lisan al-Aâab, juz XI. Beirut: Dâr al-Ilmiyah, t.t.

Al-Nabhani. Nizâm al-Islâm. cet. 6. Beirut: Mansyûrat Hizb al-Tahrir, 2001.

Nata, Abuddin. Manajemen Pendidikan: Mengatasi Kelemahan Pendidikan Islam di Indonesia. Jakarta: Kencana Prenada Media Group, 2003.

Praja, Juhaya S. Filsafat Hukum Islam. Bandung: LPPM, 2002.

Al-Qurthubi. al-Jâmi' li Anhkâm al-Qur'ân, Jilid IV. Beirut: Dâr al-Kutûb al-'Ilmiyyah, t.t.

Quthb, Sayyid. Fî Zhilâl al-Qur'ân, jilid VIII. Kairo: Dâr al-Syurûq, t.t.

Rahman (ed.). Peran Strategis Kepala Sekolah dalam Meningkatkan Mutu Pendidikan. Bandung: Alqaprint Jatinangor, 2006.

Ridho, Muhammad Rasyid. Tafsîr al-Qur'ân al-Karim: Juz 'Ammâ. Kairo: Dar al-Masyriq, t.t.

Robbins, Anthony. Unpower Limit: Kekuatan Tanpa Batas, terj. T. Zaini Dahlan. Jakarta: Pustaka Delapratasa, 2000.

Shihab, M. Quraish. Membumikan al-Qur' ân. Bandung: Mizan, 1992.

Suryadi, Ace dan Wiana Mulyana. Kerangka Konseptual Mutu Pendidikan dan Pembinaan Kemampuan Profesional Guru. Bandung: Candimas Metropole, 1992.

Syalabi, Muhammad Musthafa. Al-Madkhal fí al-Ta'ârif bi al-Fiqh al-Islâmi. Beirut: Dâr al-Nahdah al-Arabiyah, 1968.

Tafsir, Ahmad. Ilmu Pendidikan dalam Perspektif Islam. Bandung: Remaja Rosdakarya, 2007. 